\title{
AKTY PRAWA MIEJSCOWEGO W SYSTEMIE GOSPODAROWANIA ODPADAMI KOMUNALNYMI - ZAGADNIENIA WYBRANE
}

\section{ACTS OF LOCAL LAW IN THE MUNICIPAL WASTE MANAGEMENT SYSTEM - SELECTED ISSUES}

\section{STRESZCZENIE}

Artykuł przedstawia wybrane zagadnienia dotyczące stanowienia aktów prawa miejscowego w zakresie gospodarki odpadami komunalnymi w kontekście przetargów na odbiór albo odbiór i zagospodarowanie odpadów komunalnych organizowanych przez gminy.

* Magister prawa, Zakład Prawa Administracyjnego i Nauki o Administracji Wydziału Prawa i Administracji Uniwersytetu im. Adama Mickiewicza w Poznaniu. 
Jego celem jest przedstawienie wybranych zagadnień wywołujących wątpliwości w pierwszym okresie obowiązywania nowego systemu.

\section{Słowa kluczowe}

Akty prawa miejscowego; odpady komunalne; uchwały rady gminy; opłaty za gospodarowanie odpadami.

\section{ABSTRACT}

The article presents selected issues concerning the regulation of local legislation in the field of waste management. Its aim is to present selected issues causing doubts in the early period of a new system. The article shows the relationship between the acts of local law and the tenders for the collection or collection and recycling of municipal waste.

\section{Keywords}

Acts of the local law; municipal waste; the resolution of the municipal council; charges for waste management.

Ustawa z dnia 1 lipca 2011 roku o zmianie ustawy o utrzymaniu czystości i porządku w gminach oraz niektórych innych ustaw $^{1}$ (dalej: ustawa nowelizująca) zapoczątkowała głęboką reformę gminnych systemów gospodarki odpadami komunalnymi, określaną niekiedy mianem „rewolucji śmieciowej”2. Wprowadzone nią zmiany do ustawy z dnia 13 września 1996 r. o utrzymaniu czystości i porządku w gminach ${ }^{3}$ (dalej: u.c.p.g.) stały się jednym z głównych wyzwań przed którymi stanęły organy gmin VI kadencji.

Wśród podstawowych celów, jakie realizować miała ustawa nowelizująca, wskazano uszczelnienie systemu gospodaro-

1 Dz.U. z 2011 r. Nr 152, poz. 897 z późn. zm.

2 Por. W. Radecki, Utrzymanie czystości i porządku w gminach. Komentarz, wyd. IV, LEX. Podobnie: J. Klatka (red.), M. Kuźniak (red.), Gospodarowanie odpadami komunalnymi. Poradnik dla gmin, Warszawa 2012.

3 Tj. Dz.U. z 2013 r. poz. 1399 z późn. zm. 
wania odpadami komunalnymi oraz wprowadzenie właściwego sposobu monitorowania postępowania z nimi zarówno przez właścicieli nieruchomości, jak i prowadzących działalność w zakresie odbierania odpadów komunalnych od właścicieli nieruchomości ${ }^{4}$.

Realizacja celów określonych w uzasadnieniu projektu ustawy nowelizującej miała nastąpić poprzez diametralną zmianę pozycji gmin w systemie gospodarki odpadami komunalnymi. W dotychczasowym systemie (obowiązującym w większości gmin do 1 lipca 2013 roku $^{5}$ ) gminy pełniły rolę „drugoplanową". W większości przypadków ich aktywność sprowadzała się do podejmowania trzech podstawowych uchwał, mających charakter aktów prawa miejscowego, tj. uchwały w sprawie: a) regulaminu utrzymania czystości i porządku w gminach, b) górnych stawek opłat ponoszonych przez właścicieli nieruchomości za usługi w zakresie odbierania odpadów komunalnych od właścicieli nieruchomości, c) wymagań, jakie powinien spełniać przedsiębiorca ubiegający się o uzyskanie zezwolenia na odbieranie odpadów komunalnych od właścicieli nieruchomości. Sporadycznie podejmowane były, poprzedzane referendami lokalnymi, uchwały w sprawie przejęcia od właścicieli nieruchomości wszystkich lub wskazanych obowiązków wynikających z u.c.p.g. ${ }^{6}$, których wejście w życie skutkowało zmianą pozycji gminy, w szczególności jej zakresu zadań. Jednocześnie organy gminy miały kompetencje do wydawania zezwoleń na prowadzenie działalności w zakresie odbierania odpadów komunal-

4 Szerzej: uzasadnienie rządowego projektu ustawy o zmianie ustawy o utrzymaniu czystości i porządku w gminach oraz niektórych innych ustaw, druk Sejmu VI Kadencji nr 3670, [online: http://orka.sejm.gov.pl/Druki6ka. nsf/0/3CA1250258CBA9D3C12577ED003C38F7/\$file/3670.pdf, dostęp: 13 lutego 2014 r.].

5 Ostateczny termin wejścia w życie obligatoryjnych uchwał rad gmin, podejmowanych na podstawie przepisów znowelizowanej u.c.p.g. - por. art. 10 ust. 2 ustawy nowelizującej

6 Przykładowo: Gmina Izabelin - uchwała nr VI/33/11 Rady Gminy Izabelin z dnia 20 kwietnia 2011 r. w sprawie przejęcia przez Gminę Izabelin od właścicieli nieruchomości obowiązku pozbywania się zebranych na terenie nieruchomości odpadów komunalnych (Dz.Urz. Woj. Maz. z 2011 r. Nr 79, poz. 2508). 
nych od właścicieli nieruchomości. Gminy prowadziły także ewidencję umów zawartych na odbieranie odpadów komunalnych od właścicieli nieruchomości w celu kontroli wykonywania przez właścicieli nieruchomości i przedsiębiorców obowiązków wynikających z ustawy. Wybór podmiotu zajmującego się odbiorem odpadów komunalnych należał do właściciela nieruchomości (w rozumieniu u.c.p.g.), który co do zasady miał w tym zakresie pełną swobodę7. Organy gminy nie miały bezpośredniego wpływu za treść stosunku cywilnoprawnego łączącego przedsiębiorcę odbierającego odpady komunalne z właścicielem nieruchomości. W szczególności organy gminy nie miały wpływu na zakres wzajemnych praw i obowiązków obu umawiających się stron, w tym na wzajemne rozliczenia (poza ustaleniem górnych stawek opłat).

W nowym systemie gospodarki odpadami komunalnymi (obowiązującym w większości gmin od 1 lipca 2013 roku) gmina ${ }^{8}$ stała się podmiotem „centralnym”, posiadającym zdecydowanie szerszy niż poprzednio, katalog zadań oraz kompetencji służących ich realizacji. Organy gminy stały się głównym organizatorem systemu gospodarki odpadami komunalnymi. Gmina została zobowiązana do objęcia wszystkich właścicieli nieruchomości na terenie gminy systemem gospodarowania odpadami komunalnymi. Zadanie to w przypadku wszystkich nieruchomo-

7 Szerzej na temat modelu konkurencji na rynku odpadów komunalnych: Konkurencja na polskim rynku ustug odbioru i zagospodarowania odpadów komunalnych. Raport UOKiK, Warszawa 2012 [online: http://www.uokik.gov.pl/ download.php?plik=11547, dostęp: 13 lutego 2014 r.].

8 Odpowiednio związki międzygminne tworzone w celu wspólnego wykonywania przez gminy zadań publicznych wynikających ze znowelizowanej u.c.p.g. - por. art. 3 ust. 2a u.c.p.g. Przykładem takiego związku jest: Związek Międzygminny Pilski Region Gospodarki Odpadami Komunalnymi (statut opublikowany w Dz.Urz. Woj. Wielk. z 2012 r. poz. 5969 z późn. zm.). Ilekroć $\mathrm{w}$ niniejszym artykule mowa jest o gminie należy przez to odpowiednio rozumieć także związki międzygminne zajmujące się „operacyjną” stroną systemów gospodarki odpadami komunalnymi (nie dotyczy to związków mających na celu wyłącznie budowę, utrzymanie lub eksploatację regionalnych instalacji do przetwarzania odpadów). Ilekroć w niniejszym artykule mowa jest o organach gminy (rada gminy, wójt) należy przez to odpowiednio rozumieć organy związku międzygminnego (zgromadzenie związku, zarząd związku). 
ści zamieszkałych realizowane jest przez obowiązkową organizację przez gminę przetargu na odbiór albo odbiór i zagospodarowanie odpadów komunalnych ${ }^{9}$, którego celem jest wyłonienie w konkurencyjnym trybie przetargowym określonym w ustawie z dnia 29 stycznia 2004 r. Prawo zamówień publicznych ${ }^{10}$ (dalej: u.p.z.p.), podmiotu świadczącego w imieniu gminy usługę odbioru bezpośrednio od właścicieli nieruchomości określonych frakcji odpadów. Obowiązek organizacji przetargu objął także te gminy, które posiadały dotychczas własne zakłady budżetowe lub spółki komunalne świadczące usługi w zakresie odbioru odpadów komunalnych. Przepisy u.c.p.g. w tym zakresie uznawane są za regulację szczególną względem przepisów ustawy z dnia 20 grudnia 1996 r. o gospodarce komunalnej ${ }^{11}$ (dalej: u.g.k.), ograniczając tym samym samodzielność jednostek samorządu terytorialnego. Trybunał Konstytucyjny uznał jednakże, iż ograniczenie to jest zgodne z przepisami Konstytucji Rzeczypospolitej Polskiej z dnia 2 kwietnia 1997 roku $^{12}$ (dalej: Konstytucja RP), z uwagi na ochronę innych konstytucyjnych wartości (społeczna gospodarka rynkowa i wolność działalności gospodarczej, ochrona uzasadnionych konstytucyjnie oczekiwań prywatnych podmiotów prowadzących dotychczas działalność w zakresie odbioru odpadów komunalnych, ochroną środowiska) ${ }^{13}$. W wyniku skutecznego przeprowadzenia przetargu pomiędzy wyłonionym przedsiębiorcą a gminą dochodzi do nawiązania stosunku cywilnoprawnego. Jednocześnie gmina jako

9 Poza zakresem niniejszego opracowania pozostaje szczegółowa analiza różnic pomiędzy przetargiem na odbiór a przetargiem na odbiór i zagospodarowanie odpadów komunalnych. Dla potrzeb dalszych analiz przyjęto, iż pierwszy z przetargów dotyczy wyłącznie odbioru odpadów komunalnych od właścicieli nieruchomości i przekazania ich we wskazane przez gminę miejsce, drugi zaś obejmuje dodatkowo zgodne z prawem zagospodarowanie odpadów komunalnych w przeznaczonych do tego instalacjach.

10 Tj. Dz.U. z 2013 r. poz. 907 z późn. zm.

11 Tj. Dz.U. z 2011 r. Nr 45, poz. 236

12 Dz.U. z 1997 r. Nr 78, poz. 483 z późn.zm.

13 Por. wyrok Trybunału Konstytucyjnego z dnia 28 listopada 2013 r. sygn. K 17/12, sentencja ogłoszona w Dz.U. z 2013 r., poz. 1593. Szerzej: M. Kiełbus, Rewolucja śmieciowa oczami Trybunału Konstytucyjnego, „Wspólnota” 3/2014, s. 49 i nast. 
podmiot prawa publicznego staje się stroną stosunków publicznoprawnych z właścicielami poszczególnych nieruchomości zamieszkałych (wyjątkowo także niezamieszkałych, na których powstają odpady komunalne), którzy zobligowani są do uiszczania na jej rzecz publicznoprawnych opłat za gospodarowanie odpadami komunalnymi ${ }^{14}$.

Przetargi na odbiór albo odbiór i zagospodarowanie odpadów komunalnych są jednym z elementów kształtujących gminne systemy gospodarki odpadami komunalnymi, które służą realizacji zadań wynikających ze znowelizowanej u.c.p.g. Systemy te cechują się znaczną różnorodnością wynikającą ze swobody jaką ustawodawca pozostawił $\mathrm{w}$ tym zakresie organom samorządu terytorialnego realizującym przedmiotowe zadania. W konsekwencji w każdej z gmin może funkcjonować odmienny system gospodarki odpadami komunalnymi, mieszczący się w ogólnych ramach prawnych wyznaczonych w głównej mierze przepisami u.c.p.g. Różnie zatem kształtować się będą przetargi na odbiór albo odbiór i zagospodarowanie odpadów komunalnych. Różnice w tym zakresie wynikające z u.c.p.g. oraz aktów prawa miejscowego podjętych na jej podstawie potęgują przepisy u.p.z.p., które także stwarzają możliwość różnicowania zakresu przetargów (np. w zakresie długości trwania umowy).

Przetargi w przedmiotowym zakresie, stanowiąc element kształtowania gminnych systemów odpadowych, nierozerwalnie powiązane są z innymi elementami wprowadzonymi lub zmodyfikowanymi ustawą nowelizującą, w szczególności zaś $\mathrm{z}$ aktami prawa miejscowego, jakie stanowione są przez organy samorządu terytorialnego w zakresie gospodarki odpadami komunalnymi. Relacje pomiędzy zakresem organizowanych przetargów a treścią stanowionych aktów prawa miejscowego mają charakter dwustronny. Z jednej strony rozstrzygnięcia normatywne podjęte przez organy samorządu terytorialnego bezpośrednio bądź pośrednio wpływają na zakres przeprowadzanego przetargu. Z drugiej zaś strony wynik przetargu wpływa na treść niektórych uchwał o charakterze powszechnie obowiązującym.

14 Por. wyrok WSA Rzeszowie z dnia 13 listopada 2012 r., sygn. I SA/Rz 968/12. 
Nie bez znaczenia pozostaje także relacja czasowa pomiędzy podejmowaniem poszczególnych uchwał a przeprowadzeniem przetargu. Wszystkie te czynności, będąc ze sobą wzajemnie powiązane, wyznaczają określony schemat postępowania organów gminy, który miał szczególnie istotne znaczenie na etapie wdrożenia nowych rozwiązań prawnych, tj. przed 1 lipca 2013 roku. W chwili obecnej równie ważne staje się ustalenie relacji pomiędzy zmianą (nowelizacją) poszczególnych aktów prawa miejscowego a zakresem praw i obowiązków wykonawcy wyłonionego w drodze gminnego przetargu.

Celem niniejszego artykułu jest przedstawienie podstawowych relacji pomiędzy poszczególnymi aktami prawa miejscowego z zakresu gospodarki odpadami komunalnymi a organizowanymi przetargami na odbiór albo odbiór i zagospodarowanie odpadów komunalnych.

Ustawa nowelizująca dokonała zmian nie tylko w u.c.p.g., ale także w kilku innych powiązanych tematycznie ustawach, w tym w ustawie z dnia 27 kwietnia 2001 r. o odpadach ${ }^{15}$ (dalej: dawna u.o.). Zmiany te zostały następnie przeniesione do nowej ustawy z dnia 14 grudnia 2012 r. o odpadach ${ }^{16}$ (dalej: u.o.). W obu tych aktach prawnych upoważniono sejmik województwa do uchwalenia wojewódzkiego planu gospodarki odpadami (dalej: w.p.g.o.) oraz, będącej aktem prawa miejscowego, uchwały w sprawie wykonania wojewódzkiego planu gospodarki odpadami (dalej: uchwała wykonawcza). W w.p.g.o., prócz elementów wspólnych dla innych planów gospodarki odpadami ${ }^{17}$, zamieszcza się m.in.: 1) podział województwa na regiony gospodarki odpadami komunalnymi wraz ze wskazaniem gmin wchodzących w skład regionu, 2) wskazanie regionalnych instalacji do przetwarzania odpadów komunalnych w poszczególnych regionach gospodarki odpadami komunalnymi oraz instalacji przewidzianych do zastępczej obsługi tych regionów, w przypadku gdy znajdująca się w nich instalacja uległa awarii lub nie może przyjmować odpadów z innych przyczyn oraz do

15 Tj. Dz.U. z 2010 r. Nr185, poz.1243 z późn. zm.

16 Dz.U. z 2012 r. poz. 21 z późn. zm.

17 Por. art. 35 ust. 1-3 u.o. 
czasu uruchomienia regionalnych instalacji do przetwarzania odpadów komunalnych. Oba te elementy zamieszczane są następnie w uchwale wykonawczej.

Powyższe kwestie mają istotne znaczenie z punktu widzenia organizacji przetargów na odbiór albo odbiór i zagospodarowanie odpadów komunalnych. Po pierwsze, z uchwał tych wynika, w których instalacjach mogą być zagospodarowane określone frakcje odpadów ${ }^{18}$ pochodzące $\mathrm{z}$ terenu danej gminy. Stroną umowy z podmiotami prowadzącymi te instalacje może być zarówno gmina (w przypadku przetargu na odbiór), jak i przedsiębiorca wyłoniony przez gminę $\mathrm{w}$ drodze postępowania przetargowego (w przypadku przetargu na odbiór i zagospodarowanie).

Szczególna sytuacja będzie miała miejsce wówczas, gdy gmina posiada własną lub wspólną z innymi jednostkami samorządu terytorialnego ${ }^{19}$ instalację do przetwarzania odpadów komunalnych. Jeżeli instalacja ta uzyskała status instalacji regionalnej albo status instalacji zastępczej (a w danym regionie brak jest instalacji regionalnej) może jej zostać powierzone zagospodarowanie określonych frakcji odpadów, przy czym może się to odbywać w trybie bezprzetargowym (tzw. zamówienia in-house). Gmina w takiej sytuacji nie jest zobowiązana do organizacji przetargu na odbiór i zagospodarowanie, lecz może się ograniczyć wyłącznie do przetargu na odbiór. Powyższa teza wymaga pewnych uzupełnień. Po pierwsze, wybór jednego z dwóch rodzajów przetargu w powyższej sytuacji jest prawem, a nie obowiązkiem gminy. Teoretycznie można zatem przyjąć, iż gmina nawet w sytuacji posiadania własnej lub wspólnej z innymi gminami instalacji organizować będzie przetarg na odbiór i zagospodarowanie, pozostawiając wybór instalacji wyłonionemu w drodze przetargu przedsiębiorcy. Działanie takie, jakkolwiek zgodne z przepisami prawa, zdaje się być działaniem

18 Zmieszane odpady komunalne, odpady zielone oraz pozostałości z sortowania odpadów komunalnych przeznaczone do składowania.

19 Odnośnie międzygminnych instalacji do przetwarzania odpadów komunalnych por. nieprawomocny wyrok WSA w Szczecinie z dnia 22 sierpnia 2013 roku, sygn.. II SA/Sz 274/13. 
nieracjonalnym z uwagi na rachunek ekonomiczny i nakłady poczynione uprzednio $\mathrm{w}$ związku z budową konkretnej instalacji. Po drugie, należy zwrócić uwagę na niejednorodność pojęcia regionalnej instalacji do przetwarzania odpadów komunalnych. Na gruncie obecnie obowiązującej u.o. wyróżnić można bowiem cztery rodzaje instalacji regionalnych ${ }^{20}$, przy czym ich zadaniem jest zagospodarowanie różnych frakcji odpadów ${ }^{21}$. Tym samym posiadanie przez gminę jednego z rodzajów instalacji nie zwalnia jej od konieczności poszukiwania pozostałych instalacji mogących zapewnić zagospodarowanie pozostałego strumienia odpadów. W konsekwencji w większości przypadków nawet posiadanie gminnej lub międzygminnej instalacji nie wyłącza całkowicie konieczności objęcia gminnym przetargiem elementów zagospodarowania odpadów.

Dokonując analizy relacji pomiędzy gminnymi aktami prawa miejscowego a przetargami na odbiór albo odbiór i zagospodarowanie odpadów komunalnych, w pierwszej kolejności należy wskazać, iż nie wszystkie uchwały podejmowane na podstawie u.c.p.g. mają charakter obligatoryjny. Podjęcie niektórych z nich ma charakter fakultatywny, wskutek czego rozstrzygnięcie o ich uchwaleniu pozostawiono organowi stanowiącemu gminy. Wskazać również należy, iż większość uchwał w przedmiotowym zakresie winna zostać podjęta przed opracowaniem specyfikacji istotnych warunków zamówienia poprzedzającej ogłoszenie przetargu. Uchwały te bowiem wpływają bezpośrednio lub pośrednio na zakres przeprowadzanego przetargu.

Podstawową uchwałą o charakterze obligatoryjnym podejmowaną przez radę gminy jest regulamin utrzymania czystości i porządku w gminie ${ }^{22}$, którego zakres przedmiotowy wyznacza

20 Por. art. 35 ust. 6 u.o.

21 Poza zakresem niniejszego opracowania pozostaje szczegółowa analiza różnic definicji regionalnej instalacji do przetwarzania odpadów komunalnych zawartych w dawnej u.o. oraz u.o. Należy jednakże zwrócić uwagę, iż różnice w tym zakresie mogą wpływać na sposób interpretacji pozostałych przepisów u.c.p.g. oraz sposób rekonstrukcji pierwotnych zamierzeń ustawodawcy.

22 Poza zakresem niniejszego opracowania pozostaje szczegółowa analiza zakresu regulaminu utrzymania czystości i porządku w przypadku przekazania części zadań publicznych na rzecz związku międzygminnego. Nie mniej 
art. 4 ust. 2 u.c.p.g. Z punktu widzenia organizowanych przetargów szczególnie istotne są regulacje regulaminowe dotyczące: 1) wymagań w zakresie utrzymania czystości i porządku na terenie nieruchomości obejmujących prowadzenie we wskazanym zakresie selektywnego zbierania i odbierania odpadów komunalnych, w tym powstających w gospodarstwach domowych przeterminowanych leków i chemikaliów, zużytych baterii i akumulatorów, zużytego sprzętu elektrycznego i elektronicznego, mebli i innych odpadów wielkogabarytowych, odpadów budowlanych i rozbiórkowych oraz zużytych opon, a także odpadów zielonych; 2) rodzaju i minimalnej pojemności pojemników przeznaczonych do zbierania odpadów komunalnych na terenie nieruchomości, warunków rozmieszczania tych pojemników i ich utrzymania w odpowiednim stanie sanitarnym, porządkowym i technicznym; 3) częstotliwości i sposobu pozbywania się odpadów komunalnych z terenu nieruchomości. Kluczowe znaczenie ma określenie sposobu prowadzenie selektywnej zbiórki odpadów komunalnych, w szczególności zbiórki bezpośrednio przez właścicieli nieruchomości (tzw. zbiórka „u źródła"). W praktyce w tym zakresie przyjmowane są zarówno systemy dwupojemnikowe (podział frakcji selektywnej na „suche” i „mokre”) ${ }^{23}$, jak i systemy rozwiniętej selekcji ${ }^{24}$, przy czym rozróżnienie to występuje nawet w przypadku gmin bezpośrednio sąsiadujących ze sobą. Wybór określonego modelu bezpośrednio przekłada się na zakres organizowanego przetargu, który uwzględniać musi sposób postępowania z każdą z frakcji odpadów. Istotnego znaczenia mogą nabrać także przepisy dotyczące wymagań w zakresie pojemników przeznaczonych do zbierania odpadów komunalnych na terenie nieruchomości,

należy zasygnalizować istotne różnice w podejściu do tego zagadnienia występujące w praktyce samorządowej. Kwestia ta nie doczekała się do dnia dzisiejszego szerszej analizy ze strony przedstawicieli doktryny.

23 Por. uchwała nr XXXII/684/12 Rady Miasta Gdańska z dnia 29 listopada 2012 r. w sprawie Regulaminu utrzymania czystości i porządku na terenie miasta Gdańska (tj. Dz.Urz. Woj. Pom. z 2013 r. poz. 2671).

24 Por. uchwała nr XXII/447/12 Rady Miasta Gdyni z dnia z dnia 29 sierpnia 2012 r. w sprawie Regulaminu utrzymania czystości i porządku na terenie miasta Gdyni (Dz.Urz. Woj. Pom. z 2013 r. poz. 2865 z późn. zm.). 
w tym odpadów zebranych selektywnie. Jeżeli gmina przejmie na siebie obowiązek w tym zakresie (o czym szerzej w dalszej części artykułu) wymogi te wiązać będą gminę, a w dalszej kolejności przedsiębiorców działających na jej zlecenie. Szczególną uwagę należy w tym zakresie zwrócić na wymogi dotyczące pojemników przeznaczonych do gromadzenia odpadów selektywnie zebranych. Gminy niekiedy wprowadzają w tym aspekcie dość sztywne regulacje (np. kolorystyczne oznaczenie pojemników), nie dopuszczając żadnych wyjątków (np. w zakresie oznaczenia słownego lub graficznego).

Jednocześnie wymienione powyżej elementy regulaminu utrzymania czystości i porządku w gminach stanowią podstawę do określenia przez radę gminy zakresu usług gwarantowanych właścicielom nieruchomości na terenie gminy w zamian za uiszczaną opłatę za zagospodarowanie odpadami komunalnymi. Usługa ta może być świadczona na wyższym poziomie, aniżeli wynika to z regulaminu utrzymania czystości i porządku w gminach (np. w zakresie większej częstotliwości odbioru odpadów komunalnych), jednakże nie może zejść poniżej tego poziomu. Jest to zatem minimalny zakres przedmiotowy, który winien być brany pod uwagę przy opracowywaniu dokumentacji przetargowej. Istotne jest przy tym, iż w procedurze uchwalania przedmiotowej uchwały udział bierze państwowy powiatowy inspektor sanitarny opiniujący przedłożony mu projekt regulaminu. Prowadzone dotychczas kontrole funkcjonowania nowego systemu gospodarki odpadami komunalnymi wykazują znaczne zróżnicowanie regulaminów w przedmiotowym zakresie, czego najlepszym przykładem może być częstotliwość odbioru odpadów komunalnych ${ }^{25}$.

Uchwała w sprawie regulaminu utrzymania czystości i porządku w gminach wpływa bezpośrednio na drugą z obligato-

25 Por. Raport Gtównego Inspektora Ochrony Środowiska z przeprowadzonego przez Inspekcję Ochrony Środowiska ogólnokrajowego cyklu kontrolnego przestrzegania przez gminy przepisów znowelizowanej ustawy z dnia 13 września 1996 roku o utrzymaniu czystości i porządku w gminach (Warszawa, grudzień 2013) [online: http://www.gios.gov.pl/zalaczniki/artykuly/raport_z_cyklu_ kontrolnego_gmin_2013_r._-_zatwierdzony.pdf, dostęp: 13 lutego 2014 r.] 
ryjnych uchwał (która powinna zostać podjęta po uchwaleniu regulaminu), jaką jest uchwała w sprawie szczegółowego sposobu i zakresu świadczenia usług w zakresie odbierania odpadów komunalnych od właścicieli nieruchomości i zagospodarowania tych odpadów, w zamian za uiszczoną przez właściciela nieruchomości opłatę za gospodarowanie odpadami komunalnymi (por. art. 6r ust. 3 u.c.p.g.). W uchwale tej rada gminy zobligowana jest określić co najmniej: 1) ilość odpadów komunalnych odbieranych od właściciela nieruchomości; 2) częstotliwość odbierania odpadów komunalnych od właściciela nieruchomości; 3) sposób świadczenia usług przez punkty selektywnego zbierania odpadów komunalnych. Odnosząc się do poszczególnych elementów przedmiotowej uchwały, wskazać należy, iż ilość odpadów komunalnych odbieranych od właścicieli nieruchomości ma istotne znaczenie z punktu widzenia opisu przedmiotu zamówienia. Gmina dokonując określenia ilości odpadów odbieranych od jednego mieszkańca oraz znając ilość mieszkańców swojej gminy, ma możliwość w miarę dokładnego określenia ilości odpadów, które w ramach przeprowadzonego postępowania przetargowego mają być odebrane albo odebrane i zagospodarowane przez wykonawcę (oczywiście dane w tym zakresie nie będą nigdy w pełni precyzyjne $\mathrm{z}$ uwagi np. na migrację ludności). Ułatwia to zarówno oszacowanie wartości zamówienia, jak i przygotowanie oferty przez wykonawcę. Jednocześnie zaznaczyć należy, iż wprowadzenie limitu odpadów odbieranych od właścicieli nieruchomości zostało zakwestionowane przez Wojewódzki Sąd Administracyjny w Opolu² ${ }^{26}$ Sąd przyjął bowiem, kierując się wykładnią celowościową, iż gmina zobowiązana jest odebrać od właścicieli nieruchomości każdą ilość wytworzonych przez nich odpadów ${ }^{27}$. Mając na uwadze wyraźne brzmienie art. 6r ust. 3 u.c.p.g. nie sposób zgodzić się ze stanowiskiem

26 Nieprawomocny wyrok WSA w Opolu z dnia 11 lipca 2013 roku, sygn. II SA/Op 203/13 oraz nieprawomocny wyrok WSA w Opolu z dnia 30 lipca 2013 roku, sygn. II SA/Op 202/13.

27 Teza wyrażona przez WSA w Opolu odnosi się bezpośrednio do frakcji odpadów odbieranych od właścicieli nieruchomości, jednakże w przypadku jej przyjęcia należy ją pośrednio odnieść można także do frakcji odbieranych w punktach selektywnej zbiórki odpadów komunalnych. 
sądu, który dokonał wykładni contra legem. Przyjął on bowiem, iż element zmienny w każdej uchwale (ilość odpadów ustalana przez radę gminy) ma być de facto elementem stałym (w każdej uchwale winien się znaleźć zapis o odbiorze każdej ilości odpadów, a pominięcie tego elementu skutkowałoby wadliwością całego aktu prawa miejscowego ${ }^{28}$. Kolejnym obligatoryjnym element przedmiotowej uchwały jest częstotliwość odbierania odpadów komunalnych od właściciela nieruchomości, która nie może być mniejsza od częstotliwości określone w uchwale w sprawie regulaminu utrzymania czystości i porządku w gminach (o czym mowa powyżej). Częstotliwość odbierania odpadów dotyczyć musi zarówno odpadów zmieszanych, jak i poszczególnych frakcji zbieranych w sposób selektywny.

Mniejsze znaczenie dla organizowanych przetargów ma trzeci z obligatoryjnych elementów analizowanej uchwały, tj. sposób świadczenia usług przez punkty selektywnego zbierania odpadów komunalnych. W zakresie tworzenia i utrzymania punktów selektywnego zbierania odpadów komunalnych gminy posiadają dużo większą swobodę, aniżeli w zakresie odbioru odpadów komunalnych. W szczególności zastosowanie znajduje pełen katalog form realizacji zadań własnych gminy określony w u.g.k. W konsekwencji punkty selektywnej zbiórki odpadów komunalnych mogą być prowadzone przez gminne jednostki organizacyjne (samoistne, jak i niesamoistne) ${ }^{29}$. Gmina może jednakże postanowić o włączeniu zadania w postaci prowadzenia punktu selektywnej zbiórki odpadów komunalnych (utworzonego przez gminę lub wykonawcę) do przetargu na odbiór

28 Szerzej: M. Kiełbus Poprawki odpadowych rozwiąań, „Przegląd Komunalny” 1/2014, s. 27; tenże: Komentarz do artykułu B. Dziadkiewicza pt. „Limitowanie odbioru odpadów”, „Wspólnota” 24/2013, s. 51; B. Dziadkiewicz, Limitowanie odbioru odpadów, „Wspólnota” 24/2013, s. 48 i nast.

29 Por. wyrok Trybunału Konstytucyjnego z dnia z dnia 28 listopada 2013 r. sygn. K 17/12, sentencja ogłoszona w Dz.U. z 2013 r. poz. Dz.U. poz. 1593, s. 41. Podobnie stanowisko Ministerstwa Środowiska z dnia 11 października 2013 roku: „Czy gmina może powierzać własnym spółkom bądź zakładom budżetowym tworzenie punktów selektywnego zbierania odpadów komunalnych" [online: http://www.mos.gov.pl/g2/big/2013_10/3c14612d24cbfb387b1fe96970007148.pdf, dostęp: 13 lutego 2014 r.]. 
albo odbiór i zagospodarowanie odpadów komunalnych. Jedynie $\mathrm{w}$ takim przypadku analizowany element uchwały wpływać będzie na opis przedmiotu zamówienia oraz pozostałe elementy procedury przetargowej.

Elementem fakultatywnym analizowanej uchwały może być przejęcie od właścicieli nieruchomości obowiązku wyposażenie nieruchomości w pojemniki służące do zbierania odpadów komunalnych oraz utrzymywania tych pojemników w odpowiednim stanie sanitarnym, porządkowym i technicznym. Podkreślić należy, iż możliwość wprowadzenia do analizowanej uchwały dodatkowego elementu została dodana do u.c.p.g. dopiero ustawą z dnia 25 stycznia 2013 r. o zmianie ustawy o utrzymaniu czystości i porządku w gminach ${ }^{30}$, która weszła w życie 6 marca 2013 roku. W konsekwencji w przetargach organizowanych po wejściu w życie aktów prawa miejscowego podjętych na podstawie znowelizowanej w 2013 roku u.c.p.g., w przypadku zamieszczenia w przedmiotowej uchwale właściwego przepisu, zakresem przetargu można było objąć także kwestie pojemników ${ }^{31}$. Także $\mathrm{w}$ tym zakresie regulacje wynikające $\mathrm{z}$ regulaminu stanowią minimalny poziom usług świadczonych w tym zakresie przez wykonawcę. Dotyczy to zarówno wielkości pojemników czy worków, jak i częstotliwości ich mycia bądź dezynfekcji. Wynika z tego jednocześnie, iż w przetargach organizowanych wcześniej gmina nie mogła wymagać dostarczenia wszystkim właścicielom nieruchomości, jako składowej usługi podstawowej ${ }^{32}$, pojemników służących do zbierania odpadów komunalnych, jak również utrzymywania ich w należytym stanie sanitarnym, porządkowym i technicznym. W konsekwencji koszty z tym związane nie mogły stanowić podstawy kalkulacji

30 Dz.U. z 2013 r. poz. 228

31 Por. stanowisko Ministerstwa Środowiska: „Obowiązek wyposażenia nieruchomości w pojemniki" [online: http://www.mos.gov.pl/artykul/4471_zbieranie_odpadow_komunalnych/16818_obowiazek_wyposazenia_nieruchomosci_w_pojemniki.html, dostęp: 13 lutego 2014 r.].

2/2014 32 Odmiennym zagadnieniem pozostaje dostarczenie pojemników w ramach usługi dodatkowej o czym mowa w dalszej części artykułu. 
stawki opłaty za gospodarowanie odpadami komunalnymi ${ }^{33}$. Większa swoboda dotyczyła worków służących selektywnej zbiórce odpadów komunalnych w zabudowie jednorodzinnej i zagrodowej. W tym zakresie możliwa zdaje się interpretacja dopuszczająca możliwość finansowania kosztów w tym zakresie z opłaty za gospodarowanie odpadami komunalnymi, a także włączenie tego zagadnienia do organizowanego przez gminę przetargu od samego początku funkcjonowania nowego systemu.

Przepisy znowelizowanej u.c.p.g. nie przesądzają przy tym, w jakiej formie gmina, w przypadku przejęcia dodatkowych obowiązków, ma zapewnić ich realizację. Pojemniki służące do zbierania odpadów komunalnych mogą stanowić zarówno własność gminy lub jej spółki komunalnej, jak również wykonawcy wyłonionego w drodze przetargu gminnego. W tym ostatnim przypadku podjęcie fakultatywnego rozstrzygnięcia $\mathrm{w}$ analizowanej uchwale może pośrednio wpłynąć na okres, na który organizowany jest przetarg na odbiór albo odbiór i zagospodarowanie. Gmina musi się bowiem liczyć z faktem, iż włączenie do przetargu obowiązku wyposażenia nieruchomości w pojemniki wygeneruje dodatkowe koszty po stronie wykonawcy bezpośrednio wpływające na wartość przedłożonej przez niego oferty. W takiej sytuacji koszty związane z pojemnikami mogą być niższe w przypadku przetargów dłuższych. W przypadku przetargu krótkiego (np. półrocznego) wartość oferty związana $\mathrm{z}$ wyposażeniem nieruchomości w pojemniki może być nieproporcjonalnie wyższa, wpływając przez to na wysokość opłaty za gospodarowanie odpadami komunalnymi ponoszonej przez właścicieli nieruchomości.

Kolejną obligatoryjną uchwałą rady gminy, która wpływa na kształt przetargu na odbiór albo odbiór i zagospodarowanie odpadami komunalnymi jest uchwała w sprawie metody i stawki opłaty za gospodarowanie odpadami komunalnymi (por. art. 6k ust. 1 u.c.p.g.). Uchwała ta stanowi bowiem podstawę

33 Por. nieprawomocny wyrok WSA w Białymstoku z dnia 6 listopada 2013 roku, sygn. I SA/Bk 127/13. 
zaplanowania w budżecie gminy ${ }^{34}$ po stronie dochodów środków przeznaczonych na funkcjonowanie gminnego systemu gospodarki odpadami komunalnymi, w tym na sfinansowanie kosztu odbierania, transportu, zbierania, odzysku i unieszkodliwiania odpadów komunalnych. Tym samym analiza poprzedzająca podjęcie przedmiotowej uchwały winna być skorelowana z oszacowaniem całkowitego wynagrodzenie wykonawcy, stanowiącego podstawę ustalenia wartości zamówienia. Podkreślić należy, iż w zdecydowanej większości uchwał w sprawie metody i stawki opłaty za gospodarowanie odpadami komunalnymi, które podejmowane były po raz pierwszy, stawka opłaty miała charakter „techniczny” i tymczasowy. Służyła ona z jednej strony przeprowadzeniu postępowania przetargowego, $\mathrm{z}$ drugiej zaś stanowiła wypełnienie obowiązku określonego w art. 10 ust. 1 ustawy nowelizującej ${ }^{35}$. W większości gmin, po skutecznym przeprowadzeniu procedury przetargowej, stawka opłaty winna zostać urealniona poprzez uwzględnienie w kalkulacji rzeczywistych kosztów usługi świadczonej przez wykonawcę wyłonionego w przetargu.

Ostatnią z obligatoryjnych uchwał rady gminy rzutujących na kształt przetargu na odbiór albo odbiór i zagospodarowanie odpadami komunalnymi jest uchwała w sprawie terminu, częstotliwość i trybu uiszczania opłaty za gospodarowanie odpadami komunalnymi (por. art. 61 ust. 1 u.c.p.g.). Uchwała ta z pozoru nie ma znaczenia przy konstruowaniu dokumentacji przetargowej określając wyłącznie kwestie rozliczeń w relacji gmina - właściciel nieruchomości. W rzeczywistości uchwała ta wpływa na kształtowanie się strumienia dochodów gminy, które muszą być skorelowane z planowanymi wydatkami celem zachowania stabilności ekonomicznej systemu. W konsekwencji system rozliczeń pomiędzy gminą a wykonawcą, w szczegól-

34 Odpowiednio w planie finansowym związku międzygminnego tworzonego w celu wspólnego wykonywania przez gminy zadań publicznych wynikających ze znowelizowanej u.c.p.g.

35 Przepis ten nakazywał podjąć kluczowe uchwały z zakresu gospodarki odpadami komunalnymi do 31 grudnia 2012 roku pod rygorem wydania w tym zakresie zarządzeń zastępczych przez wojewodę. 
ności zaś terminy płatności, powinien uwzględniać określone w analizowanej uchwale terminy płatności ze strony właścicieli nieruchomości. Kwestia ta nadal budzi liczne wątpliwości w środowisku samorządowym. Co prawda w niektórych orzeczeniach sądy administracyjne dopuściły określanie terminu płatności opłaty za gospodarowanie odpadami komunalnymi „z góry” (przed upływem okresu rozliczeniowego, a wręcz na samym jego początku) ${ }^{36}$, nie mniej jednak budzi to uzasadnione wątpliwości ${ }^{37}$, zwłaszcza w kontekście „zaliczkowania” opłat lub powstających nadpłat. Lepszym rozwiązaniem w przedmiotowym zakresie wydaje się odpowiednie ukształtowanie systemu rozliczeń pomiędzy gminą a wykonawcą, zapewniającego odpowiednio długie terminy służące zgromadzeniu przez gminę odpowiednich środków pochodzących z opłat za gospodarowanie odpadami komunalnymi.

Oprócz uchwał obligatoryjnych znowelizowana u.c.p.g. przewiduje możliwość podejmowania przez radę gminy uchwał o charakterze fakultatywnym, które także wpływają na kształt przetargu na odbiór albo odbiór i zagospodarowanie odpadami komunalnymi. Również te uchwały mają charakter aktów prawa miejscowego.

Do tej kategorii uchwał w pierwszej kolejności zaliczyć należy uchwałę $\mathrm{w}$ sprawie podziału gminy na sektory. Normatywną podstawę jej podjęcia stanowi art. 6d ust. 2 u.c.p.g. który przewiduje, iż organ stanowiący gminy liczącej ponad 10.000 mieszkańców może dokonać podziału obszaru gminy na sektory celem zorganizowania odbierania odpadów komunalnych od właścicieli nieruchomości oraz wyznaczenia punktów selektywnego zbierania odpadów komunalnych. Podejmując przedmiotową uchwałę rada gminy winna wziąć pod uwagę liczbę mieszkańców, gęstość zaludnienia na danym terenie oraz

36 Por. prawomocny wyrok WSA w Łodzi z dnia 14 maja 2013 roku, sygn. II SA/Łd 218/13. Wyrok utrzymany w mocy wyrokiem NSA z dnia 27 września 2013 roku, sygn. II OSK 1889/13.

37 Por. M. Błachut, Wybrane problemy stanowienia aktów prawa miejscowego, dotyczacych opłaty za gospodarowanie odpadami komunalnymi, „Nowe Zeszyty Samorządowe" 1/2013. 
obszar możliwy do obsługi przez jednego przedsiębiorcę odbierającego odpady komunalne od właścicieli nieruchomości. Ustawa nie przewiduje przy tym maksymalnej ilości sektorów, jak również minimalnej ilości mieszkańców je zamieszkujących.

Nie ulega wątpliwości, iż skuteczne podjęcie tej uchwały obliguje organ wykonawczy gminy do organizacji odrębnych przetargów dla każdego z wydzielonych sektorów (por. art. 6d ust. 3 u.c.p.g). Mając na uwadze wpływ przedmiotowej uchwały na organizację przetargów, nie ulega wątpliwości, iż winna być ona podjęta przed przystąpieniem do prac zmierzających do ogłoszenia przetargu. Z możliwości podjęcia przedmiotowej uchwały korzystają zarówno gminy małe ${ }^{38}$, jak i duże miasta ${ }^{39}$ czy związki międzygminne ${ }^{40}$.

Kolejnym fakultatywnym aktem prawa miejscowego z zakresu gospodarki odpadami komunalnymi jest uchwała w sprawie odbierania odpadów komunalnych od właścicieli nieruchomości, na których nie zamieszkują mieszkańcy, a powstają odpady komunalne (por. art. 6c ust. 2 u.c.p.g.). Uchwała ta w sposób istotny skorelowana jest z zakresem przetargu na odbiór albo odbiór i zagospodarowanie odpadami komunalnymi. $\mathrm{W}$ przypadku niepodjęcia tej uchwały przetarg organizowany przez gminę obejmuje wyłącznie odbiór albo odbiór i zagospodarowanie odpadów komunalnych od właścicieli nieruchomości zamieszkałych. Właściciele nieruchomości niezamieszkałych, na których powstają odpady komunalne, pozostają w takiej sytuacji w systemie dotychczasowym opierającym się na swobodzie wyboru przedsiębiorcy odbierającego odpady komunalne w za-

38 Przykładowo: uchwała nr XXXIX/398/13 Rady Gminy Suchy Las z dnia 26 września 2013 r. w sprawie podziału obszaru gminy Suchy Las na sektory odbioru odpadów komunalnych (Dz.Urz. Woj. Wielk. z 2013 r. poz. 5712).

39 Przykładowo: uchwała nr XXIX/655/12 Rady Miejskiej Wrocławia z dnia 5 lipca 2012 r. w sprawie podziału Wrocławia na sektory odbierania odpadów komunalnych (Dz.Urz. Woj. Doln. z 2012 r. poz. 2890).

40 Przykładowo: uchwała nr VI/29/2013 Zgromadzenia Związku Międzygminnego „Gospodarka Odpadami Aglomeracji Poznańskiej” z dnia 12 marca 2013 r. w sprawie podziału obszaru Związku Międzygminnego „Gospodarka Odpadami Aglomeracji Poznańskiej” na sektory odbioru odpadów komunalnych (Dz.Urz. Woj. Wielk. z 2013 r. poz. 2828). 
mian na uiszczaną opłatę cywilnoprawną. Odbiorem odpadów z tego typu nieruchomości mogą zajmować się także zakłady budżetowe, co jest szczególnie istotne w kontekście gminnych nieruchomości niezamieszkałych. W konsekwencji w takiej sytuacji w gminie obowiązuje dualistyczny system gospodarki odpadami komunalnymi.

W przypadku podjęcia przedmiotowej uchwały na terenie całej gminy wprowadzony zostaje system jednolity. Ostatecznie tożsame zasady gospodarowania odpadami komunalnymi dotyczą zarówno właścicieli nieruchomości zamieszkałych, jak i niezamieszkałych, na których powstają odpady komunalne ${ }^{41}$. Podjęcie uchwały w tym zakresie oznacza zatem, iż gmina zobowiązuje się do zorganizowania odbioru i zagospodarowania odpadów komunalnych ze wszystkich nieruchomości, na których one powstają. Bezpośrednio wpływa to zatem na zakres organizowanego przetargu, który musi objąć także nieruchomości niezamieszkałe. W takiej sytuacji nie ma możliwości dalszego odbioru odpadów z ich terenu przez zakłady budżetowe czy spółki komunalne działające w trybie tzw. zamówienia „in-house”. Nie jest także możliwym zorganizowanie dwóch równoległych przetargów na odbiór albo odbiór i zagospodarowanie - jednego od właścicieli nieruchomości zamieszkałych, drugiego od właścicieli nieruchomości niezamieszkałych, na których powstają odpady komunalne. Należy również wskazać, iż w przypadku podjęcia przedmiotowej uchwały właściciele nieruchomości niezamieszkałych, na których powstają odpady komunalne będą mieli prawo korzystać z usług świadczonych przez punkty selektywnej zbiórki odpadów komunalnych, co w przypadku objęcia ich przetargiem na odbiór albo odbiór i zagospodarowanie odpadów komunalnych, będzie bezpośrednio wpływało na ich zakres. Analogiczna sytuacja będzie miała miejsce w przypadku przyjęcia przez gminę obowiązku właścicieli w zakresie wyposażenia nieruchomości w pojemniki służące do zbierania

41 Uchwała ta musi objąć wszystkie nieruchomości niezamieszkałe, na których powstają odpady komunalne. Nie jest możliwym wprowadzenie w tym zakresie żadnych wyłączeń - por. prawomocny wyrok WSA we Wrocławiu z dnia 24 października 2013 roku, sygn. II SA/Wr 477/13. 
odpadów komunalnych oraz utrzymywania tych pojemników w odpowiednim stanie sanitarnym, porządkowym i technicznym. Gmina zobowiązana będzie dostarczyć te pojemniki także właścicielom nieruchomości niezamieszkałych, na których powstają odpady komunalne. Także to wpłynąć może na zakres przedmiotowego przetargu.

Ostatnim aktem prawa miejscowego, który może być fakultatywnie podjęty przez radę gminy jest uchwała w sprawie dodatkowych usług świadczonych przez gminę w zakresie odbierania odpadów komunalnych od właścicieli nieruchomości i zagospodarowania tych odpadów oraz wysokość cen za te usługi. Usługi określone $\mathrm{w}$ tej uchwale nie mieszczą się w zakresie świadczeń realizowanych przez gminę w zamian za uiszczaną opłatę za gospodarowanie odpadami komunalnymi. Właściciele nieruchomości mają pełną swobodę w korzystaniu z tychże usług dodatkowych. W przypadku korzystania z nich właściciele nieruchomości ponoszą opłaty o charakterze cywilnoprawnym. Ustawodawca nie zamieścił w u.c.p.g. przykładowego zakresu usług dodatkowych pozostawiając w tym zakresie swobodę organom gminy. Jako przykładowe usługi dodatkowe wskazać można wyposażenie nieruchomości w pojemniki lub mycie i dezynfekcję tych pojemników ${ }^{42}$ (o ile obowiązki te nie zostały przejęte przez gminę jako element usługi podstawowej) czy też odbiór bezpośrednio od właścicieli nieruchomości frakcji odpadów, które nie są odbierane w ramach usługi podstawowej $^{43}$ (odpady te mogą być samodzielnie dostarczane przez właścicieli nieruchomości do punktów selektywnego zbierania odpadów komunalnych). Wątpliwości budzi natomiast, o czym była już mowa wcześniej, możliwość uznania za usługę dodatkową odbioru od właścicieli nieruchomości odpadów powsta-

42 Przykładowo: uchwała nr XIII/102/2013 Rady Miasta Jastrzębie-Zdrój z dnia 24 lipca 2013 r. w sprawie określenia rodzaju dodatkowych usług w zakresie odbierania odpadów komunalnych od właścicieli nieruchomości (Dz. Urz. Woj. Śląsk. z 2013 r. poz. 5195).

43 Przykładowo: uchwała nr XXXV/508/2013 Rady Miejskiej w Jaworznie z dnia 28 sierpnia 2013 r. w sprawie określenia rodzaju dodatkowych usług w zakresie odbierania odpadów komunalnych od właścicieli nieruchomości i zagospodarowania tych odpadów (Dz.Urz. Woj. Śląsk. z 2013 r. poz. 5578). 
łych w ilości większej, aniżeli normatyw ustalony w uchwale w sprawie szczegółowego sposobu i zakresu świadczenia usług w zakresie odbierania odpadów komunalnych od właścicieli nieruchomości i zagospodarowania tych odpadów, w zamian za uiszczoną przez właściciela nieruchomości opłatę za gospodarowanie odpadami komunalnymi.

Dwustronność relacji pomiędzy aktami prawa miejscowego z zakresu gospodarki odpadami komunalnymi a gminnymi przetargami na odbiór albo odbiór i zagospodarowanie odpadów komunalnych powoduje, iż nie tylko uchwały wpływają na przetarg, ale także przetarg (a dokładniej jego wynik) wpływa na treść niektórych uchwał. Dotyczy to w szczególności uchwały w sprawie metody i stawki opłaty za gospodarowanie odpadami komunalnymi (por. art. 6k ust. 1 u.c.p.g.). Rada gminy podejmując tę obligatoryjną uchwałę, zobligowana jest wziąć pod uwagę: 1) liczbę mieszkańców zamieszkujących daną gminę; 2) ilość wytwarzanych na terenie gminy odpadów komunalnych; 3) koszty funkcjonowania systemu gospodarowania odpadami komunalnymi, o których mowa w art. 6r ust. 2 u.c.p.g.; 4) przypadki, w których właściciele nieruchomości wytwarzają odpady nieregularnie, w szczególności to, że na niektórych nieruchomościach odpady komunalne powstają sezonowo ${ }^{44}$. Stawka opłaty określona w tej uchwale pozwolić ma na „samobilansowanie się" gminnego systemu gospodarki odpadami komunalnymi. Funkcjonowanie tego systemu nie może generować nadwyżek finansowych przeznaczanych na inne cele. System nie może także generować strat, które musiałyby być pokrywane z innych źródeł. Podstawę kalkulacji stawki stanowią koszty działań określonych w art. 6r ust. 2 u.c.p.g., do których zaliczono koszty: 1) odbierania, transportu, zbierania, odzysku i unieszkodliwiania odpadów komunalnych; 2) tworzenia

44 Art. 6k ust. 1 i 2 u.c.p.g. w zakresie, w jakim nie przewiduje maksymalnej wysokości opłaty za gospodarowanie odpadami komunalnymi został uznany za niezgodny z art. $84 \mathrm{i}$ art. 217 Konstytucji RP - patrz: wyrok Trybunału Konstytucyjnego z dnia 28 listopada 2013 r., sentencja ogłoszona w Dz.U. z 2013 r., poz. 1593. Szerzej: M. Kiełbus, op. cit. 
i utrzymania punktów selektywnego zbierania odpadów komunalnych; 3) obsługi administracyjnej tego systemu.

Wysokość tych kosztów w znacznej mierze zależeć zatem będzie od wyniku przeprowadzonego przetargu, który wpływać będzie co najmniej na koszt odbioru odpadów komunalnych. W przypadku przetargu na odbiór i zagospodarowanie jego wynik pozwoli na określenie pełnych kosztów odbierania, transportu, zbierania, odzysku i unieszkodliwiania odpadów komunalnych. Jeżeli gmina zdecyduje się objąć także jednym przetargiem organizację i utrzymywanie punktów selektywnej zbiórki odpadów komunalnych wówczas także koszty z tym związane stanowić będą podstawę kalkulacji stawki. Nie bez znaczenia pozostaje także trzecia grupa kosztów enigmatycznie określona przez ustawodawcę jako „koszty obsługi administracyjnej systemu". W przypadku rozbudowanych umownych regulacji kontrolno-sprawozdawczych generujących po stronie wykonawcy szereg obowiązków formalnych może wpłynąć to na zakres zadań administracyjnych (np. weryfikacja składanych raportów). Wówczas także ten element wpływać będzie na wysokość stawki.

Należy podkreślić, iż decyzja organu stanowiącego dotycząca stawki opłaty za gospodarowanie odpadami komunalnymi nie ma charakteru uznaniowego. Rada gminy podejmując ten akt prawa miejscowego zobowiązana jest oprzeć się na sporządzonej uprzednio rzetelnej kalkulacji ${ }^{45}$, która powinna stanowić załącznik do uzasadnienia projektu uchwały. Zmiana wysokości stawek opłat, względem przedłożonego projektu opartego na tej kalkulacji, winna wiązać się ze zmianą po stronie kosztowej funkcjonowania systemu. W przypadku podpisania umowy z wykonawcą wyłonionym w drodze przetargu zmiana ta co do zasady będzie znacząco utrudniona. Decyzja w tym zakresie musi mieć jednakże charakter merytoryczny, nie zaś polityczny. 2013 r., sygn. I SA/Bk 127/13. 
Doświadczenia pierwszych kilkunastu miesięcy funkcjonowania systemu zdają się jednak potwierdzać sytuację odwrotną ${ }^{46}$.

Z powyższego wynika, iż wysokość stawki opłaty za gospodarowanie odpadami komunalnymi ustalona przed rozstrzygnięciem przetargu na odbiór albo odbiór i zagospodarowanie miała co do zasady charakter „techniczny” i tymczasowy. Po zakończeniu postępowania przetargowego winna zostać urealniona i dostosowana do rzeczywistych kosztów odbioru i zagospodarowania odpadów komunalnych wynikających z przeprowadzonego przetargu, chyba że równolegle korekta obejmie pozostałe elementy kosztowe doprowadzając finalnie do skalkulowania stawki na dotychczasowym poziomie.

Dla wzajemnych relacji pomiędzy aktami prawa miejscowego z zakresu gospodarki odpadami komunalnymi a gminnymi przetargami na odbiór albo odbiór i zagospodarowanie odpadów komunalnych istotne znaczenie mają również późniejsze nowelizacje uchwał omówionych w niniejszym artykule. Zmiana bądź uchylenie całości albo części obowiązującej uchwały wpływać może na zakres wzajemnych praw i obowiązków pomiędzy gminą a wykonawcą ${ }^{47}$. Kwestia ta jest jednak w większości przypadków uzależniona od konkretnych zapisów dokumentacji przetargowej, w tym zawartej umowy. Przeważnie w większości przypadków nowelizacja aktów prawa miejscowego będzie wpływać bezpośrednio na zakres obowiązków po strony gminy, które nie przekładają się automatycznie na zakres obowiązków wykonawcy. Przykładowo zwiększenie częstotliwości odbioru poszczególnych frakcji odpadów w trakcie trwania umowy oznacza obowiązek zorganizowania przez gminę zwiększonej ilości odbiorów wpływając na treść stosunku administracyjnoprawnego pomiędzy gminą a właścicielem nieruchomości. Co do zasady nie przekłada się to jednak automa-

46 Dowodzą tego w szczególności dane dotyczące wysokości stawek w poszczególnych województwach - przykładowo: Raport Głównego ...

47 To samo dotyczyć będzie ewentualnego stwierdzenia nieważności całości albo części aktu prawa miejscowego przez sąd administracyjny w trybie bezpośredniej kontroli aktów prawa miejscowego sprawowanej w oparciu o przepisy ustawy z dnia 30 sierpnia 2002 roku Prawo o postępowaniu przed sądami administracyjnymi (tj. Dz.U. z 2012 r., poz. 270 z późn. zm.). 
tycznie na zakres obowiązków wykonawcy, a co za tym idzie na treść stosunku cywilnoprawnego łączącego go z gminą (chyba, że odmienna regulacja została wprowadzona do łączącej strony umowy). W niektórych przypadkach nowelizacja aktów prawa miejscowego może jednak bezpośrednio wpłynąć za sytuację wykonawcy. Przykładowo może to dotyczyć nowelizacji uchwały wykonawczej w sytuacji organizacji przetargu na odbiór i zagospodarowanie odpadów komunalnych. Zmiana przynależności gminy do regionu gospodarki odpadami komunalnymi lub zmiana statusu poszczególnych instalacji może rzutować na relacje prawne pomiędzy gminą a wykonawcą.

W kontekście powyższych uwag szczególnego znaczenia nabiera postulat dokonywania szerszych nowelizacji aktów prawa miejscowego, zwłaszcza przez organy gminy, w taki sposób, aby wprowadzane zmiany wchodziły w życie równolegle do kolejnych przetargów organizowanych przez gminę. Pozwoli to na uniknięcie szeregu problemów i wątpliwości natury prawnej wynikającej zarówno z przepisów u.c.p.g., jak i u.p.z.p.

Celem niniejszego artykułu było wykazanie wzajemnych relacji pomiędzy aktami prawa miejscowego z zakresu gospodarki odpadami komunalnymi a gminnymi przetargami na odbiór albo odbiór i zagospodarowanie odpadów komunalnych. Relacje te mają charakter niewątpliwy. Charakteryzuje je dwustronność polegająca na wzajemnym oddziaływaniu pomiędzy uchwałami a przetargiem (jego wynikiem). Z uwagi na ograniczoną formę artykułu przedstawiono tylko wybrane relacje, uznane przez Autora za kluczowe. Nie ulega wątpliwości, iż tematyka ta wymaga dalszych analiz, zwłaszcza w kontekście zapowiadanych kolejnych nowelizacji u.c.p.g.

\section{BIBLIOGRAFIA}

Błachut M., Wybrane problemy stanowienia aktów prawa miejscowego, dotyczacych opłaty za gospodarowanie odpadami komunalnymi, „Nowe Zeszyty Samorządowe” 1/2013.

Dziadkiewicz B., Limitowanie odbioru odpadów, „Wspólnota” 24/2013. Kiełbus M., Komentarz do artykutu B. Dziadkiewicza pt. "Limitowanie 2/2014 odbioru odpadów”, „Wspólnota” 24/2013. 
Kiełbus M., Poprawki odpadowych rozwiązań, „Przegląd Komunalny” $1 / 2014$.

Kiełbus M., Rewolucja śmieciowa oczami Trybunału Konstytucyjnego, „Wspólnota” 3/2014.

Klatka J. (red.), Kuźniak M. (red.), Gospodarowanie odpadami komunalnymi. Poradnik dla gmin, Warszawa 2012.

Radecki W., Utrzymanie czystości i porządku w gminach. Komentarz, wyd. IV, LEX.

Kontakt e-mail:

mkielbus@amu.edu.pl 